\title{
PENGARUH PENGGUNAAN E-MODUL PENGAYAAN ISOLASI DAN KARAKTERISASI BAKTERI UNTUK MENINGKATKAN KEMANDIRIAN BELAJAR SISWA SMA
}

\section{THE EFFECT OF USING THE ENHANCEMENT E-MODULE ISOLATION AND CHARACTERIZATION OF BACTERIA TO IMPROVE SELF-LEARNING REGULATION}

\author{
Dyah Aniza Kismiati ${ }^{1}$ \\ ${ }^{1}$ Alumni Program Studi Pendidikan Biologi, Program Pascasarjana UNY, Yogyakarta, Indonesia \\ *Email: anizady93@gmail.com \\ Diterima: 02 Oktober 2021. Disetujui: 17 November 2021. Dipublikasikan: 25 Desember 2021
}

\begin{abstract}
Abstrak: Penelitian ini bertujuan untuk mengetahui pengaruh penggunaan e-modul pengayaan dalam meningkatkan kemandirian belajar siswa SMA. Penelitian ini merupakan penelitian quasi eksperimen dengan desain nonequivalent pretest posttest control group. Sampel penelitian yaitu siswa SMA N 1 Jetis Bantul yang terdiri atas 2 kelas. Sampel ini diambil berdasarkan teknik purposive sampling, kelas X MIPA 5 sebagai kelas kontrol dan kelas X MIPA 1 sebagai kelas eksperimen. Instrumen yang digunakan berupa angket dan lembar observasi kemandirian belajar siswa. Data dianalisis melalui Independent Sample T-Test dan Normalized Gain Score ( $N$-Gain Score). Hasil penelitian menunjukkan bahwa E-modul yang dikembangkan berpengaruh secara signifikan terhadap kemandirian belajar siswa yang dibuktikan dengan nilai signifikansi $0.000<\alpha 0.05$ dan kategori peningkatan sedang dari hasil penghitungan $N$-Gain Score sebesar 0.307 .
\end{abstract}

Kata kunci: E-modul, pengayaan, bakteri, kemandirian belajar.

\begin{abstract}
This study aims to determine the effect of the use of enrichment e-modules in increasing the learning independence of high school students. This research is a quasi experimental study with nonequivalent pretest posttest control group design. The sample of the study is Jetis 1 High School students Bantul consisting of 2 classes. This sample was taken based on purposive sampling technique, class X MIPA 5 as a control class and class X MIPA 1 as an experimental class. The instruments used were questionnaires and observation sheets for students' learning independence. Data were analyzed through Independent Sample T-Test and Normalized Gain Score (NGain Score). The results showed that the E-module developed had a significant effect on student learning independence as evidenced by the significance value of $0,000<\alpha 0.05$ and the category of moderate improvement from the calculation of N-Gain Score of 0.307.
\end{abstract}

Keywords : Science learning outcomes, Problem Based Learning, Communication Skill

\section{PENDAHULUAN}

Pembelajaran diartikan sebagai proses interaksi peserta didik dengan pendidik dan sumber belajar pada suatu lingkungan belajar [1]. Selama pembelajaran berlangsung, dilakukan pula evaluasi baik secara formatif maupun sumatif untuk mengetahui kemajuan proses belajar siswa. Dari hasil evaluasi tersebut, akan menempatkan siswa ke dalam kelompok atas dan bawh yang masing-masing diantaranya memerlukan tindak lanjut. Siswa yang berada dalam kelompok bawah diberikan penanganan berupa pemberian program remedial, sedangkan siswa yang berada di kelompok atas, yaitu dengan nilai diatas KKM akan diberikan tindak lanjut berupa pemberian program pengayaan.

Program pengayaan adalah program pendalaman materi pembelajaran yang diperuntukkan bagi siswa yang telah melampaui nilai Kriteria Ketuntasan Minimal (KKM). Berbeda dengan program remedial, pada program pengayaan menekankan pada penguatan aspek kompetensi yang sudah dikuasai siswa [2]. Program pengayaan dapat dilaksanakan melalui pembelajaran kelompok, pembelajaran mandiri, maupun pembelajaran berbasis tema [3] Pemilihan program pengayaan tersebut disesuaikan dengan karakteristik dan kebutuhan siswa.

Hasil wawancara dan observasi yang dilakukan di sebuah di SMA negeri di Kabupaten Bantul, mengungkap fakta bahwa program pengayaan yang dilakukan oleh guru biologi kelas $\mathrm{X}$ berupa program pengayaan belajar mandiri. Belajar mandiri adalah jenis program pengayaan dimana siswa yang telah mencapai penguasaan $100 \%$ ataupun siswa yang telah melampaui nilai KKM namun belum mencapai penguasaan $100 \%$ menjadi tutor bagi sesamanya (tutor sebaya). Namun karena adanya keterbatasan waktu, program pengayaan ini hanya dilakukan sesekali dan berupa pemberian tugas yakni latihan mengerjakan soal-soal dengan materi yang lebih mendalam yang belum disampaikan guru pada pembelajaran umum di kelas.

Sebenarnya, pengayaan secara mandiri dapat dilakukan dengan memanfaatkan sumber belajar. Namun sayangnya, sumber belajar untuk program pengayaan terutama pada mata pelajaran biologi masih terbatas. Apalagi yang terkait dengan materi bakteri pada Kompetensi Dasar (KD) 3.5. Hasil observasi dan wawancara dengan guru biologi yang mengajar di kelas $\mathrm{X}$ menunjukkan bahwa 
kemandirian belajar siswa masih rendah terutama terkait dengan referensi sumber belajar, dimana para siswa masih ketergantungan dengan sumber belajar yang berasal dari guru. Padahal, dari hasil wawancara yang dilakukan kepada beberapa orang siswa SMA, mereka memiliki ketertarikan terhadap materi bakteri.. Terlebih lagi jika materi disampaikan dalam bentuk elektronik yang menarik dan dapat diakses kapanpun dan dimanapun. Oleh karena itu, sumber belajar mandiri untuk program pengayaan materi bakteri di SMA sangat dibutuhkan.

Sumber belajar elektronik seperti E-modul dapat disusun berdasarkan hasil penelitian yang telah dilakukan. Penggunaan hasil penelitian sebagai dasar dari penyusunan sebuah sumber belajar (research based learning) akan memperkaya materi dan sajian fakta yang lebih nyata bagi siswa, sehingga diharapkan akan dapat meningkatkan hasil belajar dan kemandirian belajar siswa.

Hasil belajar dikatakan berhasil bila pembelajaran tersebut dianggap bermakna bagi siswa. Pembelajaran bermakna (meaningfull learning) seperti yang diungkapkan oleh Ausubel merupakan proses mengaitkan informasi atau materi baru dengan konsep-konsep yang telah ada dalam struktur kognitif [4]. Pembelajaran akan lebih bermakna apabila tema yang dibahas adalah sebuah isu yang sedang hangat-hangatnya diperbincangkan di kalangan siswa.

Siswa SMA sebagai remaja terutama bagi remaja wanita, menganggap bahwa penampilan adalah hal yang penting untuk diperhatikan. Oleh karena itu, untuk memenuhi harapan memiliki penampilan yang ideal, kerap kali para siswi melakukan diet dan menggunakan kosmetik untuk menunjang penampilan. Salah satu produk yang dapat digunakan sebagai bahan diet maupun bahan campuran pembuatan kosmetik (seperti masker wajah) bagi remaja adalah yoghurt. Yoghurt merupakan produk fermentasi yang berasal dari bakteri Lactobacillus bulgaricus. Bakteri ini merupakan salah satu jenis bakteri asam laktat. Selain bermanfaat dalam pembuatan produk fermentasi, bakteri asam laktat juga memiliki banyak keuntungan bagi manusia, terlebih sebagai bakteri probiotik.

Terkait dengan isu bakteri probiotik, terdapat penelitian berkenaan dengan Isolasi, Seleksi, dan Karakterisasi Bakteri Asam Laktat dari Intestinum Itik Manila Sebagai Kandidat Probiotik oleh Puput Saputri (2018) yang sebenarnya dapat dijadikan sebagai sumber belajar yang menarik bagi siswa. Hasil penelitian ini juga cocok digunakan untuk memperdalam materi bakteri pada KD 3.5 pada program pengayaan mengingat penjabaran sub materi terkait inokulasi dan pengecatan gram masih sangat minim diberikan pada saat pembelajaran reguler di kelas.

Penggunaan sumber belajar tidak hanya bertujuan untuk meningkatkan hasil belajar siswa terutama untuk ranah kognitif, melainkan juga bertujuan untuk megembangkan ranah sikap dan keterampilan. Beberapa penelitian menunjukkan bahwa dengan penggunaan sumber belajar maka akan lebih memandirikan siswa dalam belajar. Oleh karena itu, bila pembelajaran bertujuan untuk memperdalam materi seperti dalam program pengayaan maka akan sangat bermanfaat bila menggunakan sumber belajar terlebih yang berbasis hasil penelitian.

\section{METODE PENELITIAN}

Penelitian ini dilakukan di SMA Negeri 1 Jetis, Bantul , Yogyakarta pada semester ganjil tahun ajaran 2017/2018. Jenis penelitian ini adalah Quasi Exsperiment. Variabel bebas dalam penelitian ini adalah.penggunaan e-modul pengayaan isolasi dan karakterisasi bakteri, sedangkan variabel terikat yaitu kemandirian belajar siswa. Instrumen yang digunakan untuk mengetahui kemandirian siswa sebelum dan selama menggunakan E-modul ini berupa lembar angket kemandirian belajar dan lembar observasi kemandirian belajar.

Angket kemandirian menggunakan skala Likert dengan lima alternatif pilihan yaitu TP (tidak pernah), J (jarang), K (kadang-kadang), SR (sering) dan SL (selalu). Lembar angket dan lembar observasi (yang diisi oleh peer reviewer) kemandirian belajar mengacu pada 4 aspek kemandirian, yaitu aspek inisiatif, bertanggungjawab, motivasi, dan responsif.

Data dari angket berskala likert ini diubah menjadi data kuantitatif sesuai Tabel 1.

Tabel 1. Konversi Penilaian Skala Likert dalam Skor

\begin{tabular}{lc}
\hline Penilaian & Skor \\
\hline Sangat Baik (SB) & 5 \\
\hline Baik (B) & 4 \\
\hline Cukup (C) & 3 \\
\hline Kurang (K) & 2 \\
\hline Sangat Kurang (SK) & 1 \\
\hline
\end{tabular}

Penghitungan skor rata-rata dari setiap aspek yang dinilai dilakukan dengan rumus:

$$
\mathrm{X}=\mathrm{x} / \mathrm{n}
$$

Keterangan :

$\mathrm{X}=$ skor rata-rata;

$\mathrm{x}=$ jumlah skor;

$\mathrm{n}=$ jumlah reviewer/responden

Selanjutnya konversi skor rata-rata ke nilai 100 dengan cara:

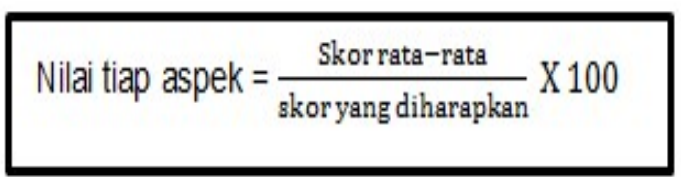

Untuk mengetahui peningkatan kemandirian belajar siswa maka dilakukan adaptasi penghitungan skor 
pencapaian ternormalisasi (normalized gain score). Rumus gain score ternormalisasi yaitu:

$$
\mathrm{g}=\frac{\text { skor posttest }- \text { skor pretest }}{\text { skor maksimum }- \text { skor pretest }}
$$

Dalam hal ini, skor posttest adalah nilai kemandirian belajar siswa setelah menggunakan Emodul pengayaan isolasi dan karakterisasi bakteri, sedangkan skor pretest adalah nilai kemandirian belajar siswa sebelum menggunakan E-modul pengayaan isolasi dan karakterisasi bakteri.

Hasil rerata nilai (g), digunakan untuk mengetahui peningkatan kemandirian dan hasil belajar siswa dalam penggunaan $E$-modul pengayaan berdasarkan kategori gainscore ternormalisasi menurut Hake [5] disajikan pada Tabel 2.

Tabel 2. Kategori $N$-gain score

\begin{tabular}{|c|c|}
\hline Nilai gain score ternormalisasi & Kategori \\
\hline $\mathrm{g}>0,70$ & Tinggi \\
\hline $0,70>\mathrm{g}>0,30$ & Sedang \\
\hline $0,30>\mathrm{g}$ & Rendah \\
\hline
\end{tabular}

\section{HASIL DAN PEMBAHASAN}

Salah satu tujuan pengembangan E-modul pengayaan ini adalah untuk meningkatkan kemandirian belajar siswa dalam program pengayaan secara mandiri. Dengan menggunakan E-modul pengayaan ini diharapkan siswa dapat memperdalam pengetahuannya mengenai kingdom monera khususnya bakteri tanpa harus bergantung dari guru ataupun orang lain.

Peningkatan kemandirian belajar siswa pada kelas kontrol dan eksperimen dapat diketahui berdasarkan Normalized Gain Score ( $N$-gain score). Hasil analisis ditunjukkan dalam Tabel 3 dan Tabel 4.

Tabel 3. Normalized Gain Score Peningkatan Kemandirian Belajar Siswa pada Kelas Kontrol

\begin{tabular}{ccc}
\hline Nilai & $\begin{array}{c}\text { Nilai } \\
\text { Kemandirian } \\
\text { Sebelum } \\
\text { Pembelajaran }\end{array}$ & $\begin{array}{c}\text { Nemandirian } \\
\text { Selama } \\
\text { Pembelajara } \\
\text { n }\end{array}$ \\
\hline Nilai Terendah & 56,67 & 65,33 \\
\hline Nilai Tertinggi & 72,67 & 80 \\
\hline Rata-rata Nilai & 71,72 & 72,67 \\
\hline $\begin{array}{c}\text { Rata-rata Gain } \\
\text { Score }\end{array}$ & \multicolumn{3}{c}{$\mathbf{0 , 0 0 4}$} \\
\hline $\begin{array}{c}\text { Kategori Gain } \\
\text { Score }\end{array}$ & \multicolumn{2}{c}{ Rendah } \\
\hline
\end{tabular}

Tabel 4. Normalized Gain Score Peningkatan Kemandirian Belajar Siswa pada Kelas Eksperimen

\begin{tabular}{|c|c|c|}
\hline Nilai & $\begin{array}{c}\text { Nilai } \\
\text { Kemandirian } \\
\text { Sebelum } \\
\text { Pembelajaran }\end{array}$ & $\begin{array}{c}\text { Nilai } \\
\text { Kemandirian } \\
\text { Selama } \\
\text { Pembelajaran }\end{array}$ \\
\hline $\begin{array}{c}\text { Nilai } \\
\text { Terendah }\end{array}$ & 58 & 74,67 \\
\hline $\begin{array}{c}\text { Nilai } \\
\text { Tertinggi }\end{array}$ & 80,67 & 88,67 \\
\hline
\end{tabular}

\begin{tabular}{|c|c|c|}
\hline Nilai & $\begin{array}{c}\text { Nilai } \\
\text { Kemandirian } \\
\text { Sebelum } \\
\text { Pembelajaran }\end{array}$ & $\begin{array}{c}\text { Nilai } \\
\text { Kemandirian } \\
\text { Selama } \\
\text { Pembelajaran }\end{array}$ \\
\hline $\begin{array}{c}\text { Rata-rata } \\
\text { Nilai }\end{array}$ & 71,90 & 80,83 \\
\hline $\begin{array}{c}\text { Rata-rata Gain } \\
\text { Score }\end{array}$ & \multicolumn{2}{|c|}{$\mathbf{0 , 3 0 7}$} \\
\hline $\begin{array}{c}\text { Kategori Gain } \\
\text { Score }\end{array}$ & Sedang \\
\hline
\end{tabular}

Hasil penelitian menunjukkan bahwa

kemandirian belajar siswa pada kelas kontrol dan eksperimen sama sebelum pembelajaran dalam program pengayaan dilakukan. Setelah dilakukan pembelajaran pada program pengayaan dengan menggunakan E-modul pengayaan isolasi dan karakterisasi bakteri pada kelas eksperimen dan tanpa menggunakan E-modul pengayaan pada kelas kontrol, ternyata kemandirian belajar siswa meningkat, dan pada kelas eksperimen, rata-rata kemandirian belajar siswa lebih tinggi daripada di kelas kontrol seperti yang dapat dilihat pada Gambar 1.

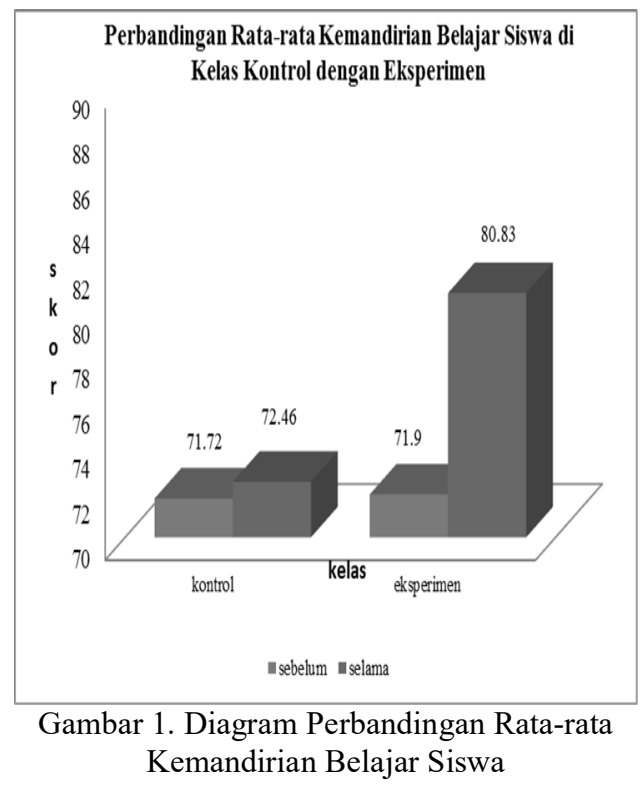

Gambar 1 tersebut menunjukkan bahwa penggunaan E-modul pengayaan isolasi dan karakterisasi bakteri mendorong siswa menjadi lebih mandiri dalam belajar sebab E-modul pengayaan ini bersifat self instruction dan self contained yang memungkinkan siswa dapat belajar secara mandiri sesuai dengan gaya dan kecepatan belajar setiap siswa [6] Hasil observasi yang dilakukan oleh observer yakni para peer reviewer mendeskripsikan bahwa terjadi peningkatan kemandirian belajar di kelas eksperimen. Peningkatan tersebut terlihat pada aspek kemandirian belajar khususnya pada aspek inisiatif yakni dengan adanya beberapa siswa yang memberikan pertanyaan dan juga tanggapan dalam 
proses pembelajaran dengan menggunakan e-modul pengayaan.

Peningkatan kemandirian belajar pada siswa yang menggunakan $E$-modul pengayaan ini diperkuat dengan hasil analisis statistika inferensial dengan uji $\mathrm{t}$ tidak berpasangan (independent sample t-test), yang menunjukkan nilai signifikansi $0,000<0,05$, yang berarti bahwa peningkatan kemandirian belajar siswa pada kelas eksperimen dengan kontrol berbeda secara signifikan.

Perubahan sikap seperti peningkatan kemandirian belajar pada diri seorang siwa setelah pembelajaran disebabkan oleh beberapa faktor, salah satunya adalah motivasi. Ana Maria [7] mengungkapkan bahwa motivasi berhubungan dengan perkembangan kemandirian belajar seseorang, bahkan motivasi menjadi faktor yang mendasari proses kemandirian itu sendiri. Dalam $E$ modul pengayaan ini juga telah berisi umpan balik yang dapat memotivasi siswa untuk meningkatkan kemandiriannya, namun akan lebih baik juga jika motivasi tersebut disampaikan oleh guru dan lingkungan belajar yang ada disekitar siswa seperti keluarga.

\section{KESIMPULAN}

Berdasarkan tujuan dan hasil penelitian, dapat disimpulkan bahwa: E-modul pengayaan isolasi dan karakterisasi bakteri yang dikembangkan berpengaruh secara signifikan terhadap kemandirian belajar siswa kelas X di SMA N 1 Jetis, Bantul yang dibuktikan dengan nilai signifikansi $0,000<\alpha 0,05$ dan kategori peningkatan sedang dari hasil penghitungan $N$-Gain Score sebesar 0,307.

\section{DAFTAR PUSTAKA}

[1] Depdiknas .2003. Undang-undang RI No.20 tahun 2003.tentang sistem pendidikan nasional.

[2] Subali, Bambang. (2016). Prinsip Asesmen dan Evaluasi Pembelajaran.Edisi Kedua. Yogyakarta: UNY Press.

[3] Ausubel , D.P,. (1963), The Psycholoy of meaningful verbal Learning, New York : Grune \& Stratton Publishers.

[4] Direktorat Pembinaan Sekolah Menengah Atas. (2017). Panduan Penilaian: Oleh Pendidik dan Satuan Pendidikan Sekolah Menengah Atas. Jakarta: Kemdikbud.

[5] Hake, R. R. (1999). Analyzing Change/ Gain Score. Indiana: Indiana University.

[6] Aryanto. (2013). Menyusun Modul. Yogyakarta: Gava Media.

[7] Ana Maria Cazan. (2011). Student Motivation And Self-Regulated Learning - A Theoretical Review. 